\title{
Dvakrát o Karlu Čapkovi
}

\author{
Alexej Mikulášek (Praha)
}

Agnieszka Janiec-Nyitrai: Zrcadlení. Literárněvědné sondy do tvorby Karla Čapka. Nitra: Univerzita Konštantína Filozofa, 2012. 165 s. ISBN 978-80-558-0155-1.

Mirna Šolić: Slovo a obraz: Karel Čapek a žánr cestopisu. Olomouc: Vydavatelství Filozofické fakulty Univerzity Palackého, 2015. 181 s. ISBN 978-80-87859-26-9.

Jedním z českých spisovatelů, jenž se těší kontinuitní pozornosti zahraničních bohemistů a slavistů, je Karel Čapek. Jedna z nejvýraznějších osobností české, středoevropské i evropské meziválečné literární kultury. Přirozeně se řadí, vedle Bohumila Hrabala, Jaroslava Haška a Milana Kundery (jazykem i kulturou francouzsko-českého či česko-francouzského) i Franze Kafky (areálově českého, jazykem německého a původem židovského autora), $\mathrm{k}$ oněm autorům, jejichž dílo představuje svébytný vklad českého (popř. „pražského“) kulturního prostoru do evropského, resp. světového písemnictví. Někomu by se mohlo zdát, že se některé žánry jeho díla ocitly v jakémsi stínu velkých románů a dramat, jako je napřr. RUR, jež jako první z Čapkových dramat „obletělo celý svět" a dalo mu dnešní internacionalismus, slovo „robot“. Není to samozřejmě pravda, to však nebrání objevování nových významových vrstev a kontextů, jak dokládají i dvě níže recenzované publikace. Na úvod jen připomeňme, že Čapkovo dílo bylo publikováno nejen v drtivé většině evropských zemí (a samozřejmě v USA a v Kanadě), přeloženo snad do všech evropských literárních jazyků, ale jeho romány, povídky, apokryfy, moderní pohádky, sloupky, reportáže, črty, kritiky, překlady a samozřejmě i dramata se objevily v edičních plánech nakladatelství takových měst, jakými jsou Baku, Bombaj, Buenos Aires, Dušanbe, Havana, Jerevan, Jeruzalém, Káhira, Peking, Rio de Janeiro, Sao Paolo, Santiago de Chile, Soul, Tokio, Jokohama nebo Tel Aviv (máme-li jmenovat alespoň knižní svazky, jež eviduje ve svém fondu Národní knihovna v Praze).
Z hlediska námi posuzovaných knižních čapkologických („čapkovských“?) monografií, jejichž autorky jsou zahraniční bohemistky a slavistky, není bez zajímavosti, že i v době Karlu Čapkovi ne zcela příznivé, v první polovině padesátých let, to byli právě badatelé ze zahraničí, napřr. slovenští (Alexander Matuška) nebo ruští (Sergej V. Nikolskij), popř. polští (Halina Janaszek-Ivaničková), kteří (znovu)objevovali v jeho uměleckých textech manifestované (nebo skryté) umělecké, filozofické i humanistické hodnoty, ovšem u nás dílem ignorované, dílem popírané aktéry českého poúnorového vývoje. Dílo Karla Čapka ovšem vycházelo v Moskvě stejně jako v Berlíně nebo Varšavě a v dalších zemích „socialistického bloku“, včetně bývalé Jugoslávie, i když v letech 1949 a 1950 neeviduje Národní knihovna v podstatě jediný u nás vydaný Čapkův titul (všechna vydání jsou zahraniční provenience). Přesto je matoucí tvrdit, jak často slyšíme, že Čapek v padesátých letech nevycházel, že byl „zakázaný“: připomeňme jen, zástupně, že i v první polovině padesátých let vycházely mj. Čapkovy cestopisy jako Cesta na sever (v roce 1955), Cesta Europou (v roce 1955), Dášeňka čili život štěněte (1955), nalezneme i slovenský výbor Drobnôstky z obidvoch vrecák a iné poviedky (1954), dále vyšla Kniha apokryfu (1955), text dramatu Matka (1948, 1951, 1954), Obrázky z domova (1953, 1954), Pohádky Karla Čapka (1954), Povidky a drobné prózy (1955), Pruní parta (1948, 1954), Válka s mloky (1949, 1953, 1954), Velká kočiči pohádka (dram., 1954), Vesele o lidech (1955) nebo Výlet do Španěl (1948). A stejně zajímavé bude i srovnání těchto titulů $\mathrm{s}$ díly vy- 
dávanými v prvních letech Protektorátu Čechy a Morava, resp. v letech 1940 a 1941 (v dalších letech - až do května 1945 - Čapek nevycházel), srov. Boži muka (v roce 1941), Hordubal (v roce 1940 a 1941), Jak se co dèlá (v roce 1940 a 1941), Loupežnik (1941), Marsyas čili na okraj literatury (1941), Mèl jsem psa a kočku (1941), O knihách a čtenář́ch (1941), O lidech (1940 a 1941), Povidky z druhé kapsy (1940, 1941), Povídky z jedné kapsy (1941), Pruni parta (1940), RUR (1940), Továrna na absolutno (1940), Trapné povidky (1940), Věc Makropulos (1941), Výlet do Španěl (1940), Zahradnikưv rok (1941), Život a dilo skladatele Foltýna (1940, 1941). Většinu z nich publikovalo pražské nakladatelství F. Borového.

První recenzovanou monografii napsala Agnieszka Janiec-Nyitrai a nazvala ji Zrcadlení. Literárněvědné sondy do tvorby Karla Čapka. Publikace vznikla v rámci projektu VEGA Stredoeurópsky areál a jeho kultúrne dimenzie a navazuje na autorčina studia meziválečné české literatury, zaměřující se na dílo Karla Čapka. Svoji doktorskou práci publikovala pod názvem Svět mezi řádky. Kapitoly o cestopisech Karla Čapka též v Nitře roku 2011.

Monografie je psána částečně žurnalistickým, popř. populárně naukovým stylem, který bude blízký studentům kupřr. bohemistiky a slavistiky, stejně tak i poučeným laikům (,V čem tedy spočíuá aktuálnost a univerzalita Čapkovy tvorby? Podstatnou roli hraje jistě bohatý jazyk, který stále překvapuje svou svěžesti a vynalézavostí. Jazyk plný básnických obratů [...]. Tím, co podle nás čini z Karla Čapka autora stále čteného, nejen ctěného, je mimořádně svě̌zi, neotřelý pohled na svět, neobryklý zpuisob pátráni po podstatě jednotlivých jevui a také univerzálni tematika jeho tvorby," s. 5). Na jedné straně se tak autorka vystavuje výtce povrchnosti či dokonce frázovitosti, zvláště slyšitelné z řad ctitelů „čistě akademického stylu“, na druhou stranu však „žurnalismus“ a „didaktičnost“ v textu monografie, projevující se stylovou přístupností, konkrétností, metaforičností (slovem esejistickou „čtivostí“) nemusí být na závadu (samozrejmě pokud jsou všechna tvrzení doložena a uveden zdroj, tedy nezůstává jen u proklamací).
Autorka si kladla za cíl „na základě analýzy jednotlivých děl Karla Čapka poukázat na mnohostrannost jeho umèleckého pohledu i na různé zpüsoby Čapkova vnimáni skutečnosti, ,zrcadleni" světa a samotného člověka“, přičemž v první části se věnuje několika tematickým okruhům, a to tematice otcovství v „noetické trilogii“ (s. 11-22), vztahu kultury a prŕírody v Čapkových cestopisech (s. 25-35), rovněž tak otázkám „smichu a komiky“, resp. grotesknosti v komparatistickém pohledu (s. 37-59), stejně tak i konceptualizaci člověka jako „tvora kulturního“ (s. 61-71, na pozadí srovnání Čapkových Italských listů s Barbarem $v$ zahradě polského básníka a esejisty Zbigniewa Herberta). V druhé části se východiskem autorčiných úvah stalo „viděni a vnimáni složitosti a nejednoznačnosti lidského nitra", tematika identity a její sebereflexe, a to „paradoxy outsiderstvi v dramatu Bílá nemoc (s. 79-83), „individualistické mýty“ románu Krakatit (s. 87-92), „identita umělce" v tzv. noetické trilogii, Povídkách z jedné a z druhé kapsy a v Životě a dile skladatele Foltýna (s. 95-106), identita coby „souhrn rozdilü“ v RUR, Bilé nemoci, Povětroni, Obyčejném životě, Válce s mloky a v cestopisech (s. 109-116). Monografii uzavírají Čapkovy reflexe česko-slovenské, „o Slovácích a Slovensku“ (s. 119-129).

Vytčený cíl se badatelce z větší části podařilo naplnit. Škoda však, že v textu monografie je př́tomno tolik dílčích témat, že samotný rozsah monografického textu neumožňuje souvislejší a detailnější rozbor. Mnoho je tak naznačeno, konturováno, jakkoli většinou správně, v souladu s texty studovaných Čapkových próz. Zvláště „zrcadlení“ (jeho podoby) je přítomno v odborném textu jako centrální badatelský leitmotiv. Podnázev „sondy“ tak vystihuje autorčin záměr.

Některé autorčiny představy ovšem mohou budit diskusi. Např. nelze určit, z čeho badatelka usuzuje, že „Povětroň“ je jméno (př́ijmení? šifra?) postavy stejnojmenného románu, když se jedná o starší výraz pro „meteor“, „létavici“, což má jistou symboliku (jako řada jiných motivů v „noetické trilogii“, např. v Hordubalovi motiv,,srdce“, které se „kamsi ztratilo“, nejen jako pitevní, fyzický předmět). Čapkova postava totiž nemá téměř žádnou „občanskou“ ani jinou 
identitu (zjevila se náhle a nečekaně, jako meteorit, je výzvou stejně jako meteor na obloze), tu „rekonstruuji“ jiné postavy, které do ní částečně vnášejí vlastní zkušenosti, očekávání, představy a zájmy, své "Já“. Samotné slovo „povětroň“ zazní v textu románu jen jednou (srov. „dorazil na konec své cesty jako povětroň, ve chvatu nejhroznějším“).

Problematické je rovněž tvrzení, že Vůdce Mloků, Chief Salamander, ,je clověkem" (s. 42), jakkoliv tuto větu v románě najdeme $\mathrm{v}$ podobě odpovědi na otázku („,v uvozovkách“), zda je „on opravdu Mlok? Ne. Chief Salamander je člověk. Jmenuje se vlastně Andreas Schultze a byl za světové války někde šikovatelem." Čteme průhlednou narážku na jistého Schicklgrubera-Hitlera, a to v kapitole Autor mluvi sám se sebou. Ani z ní nevyplývá, že by lidé jako celek začali Mloky „napodobovat, tancuji stejně jako oni, chovaji se jako oni“ (s. 42), resp. že by se lidé stali Mloky. Komično i tragično či groteskno je přece naopak dáno tím, že se Mloci „polidštují“, popř. že někteří lidé jsou „advokáty“ Mloků, že pomáhají jejich expanzi zdůvodňovat a ospravedlňovat. Šance lidstva je dle „autora“ (takto označeného subjektu v citované kapitole) dána tím, že Mloci budou pokračovat v započatém díle napodobování „elit“, „autorit“ a režimů nejen na Západě a že obrátí zbraně proti sobě, ve „jménu Kultury a Práva“, a jako rod možná vyhynou na následky svých vlastních činů. Je ovšem jisté, že v Mlocích cosi lidského najít můžeme - v převráceném světle, jako ztělesnění toho špatného v lidech, kteří je do jisté míry „stvořili“.

Za méně spornou můžeme naopak pokládat interpretaci prostoru v Čapkových cestopisech, a to na ose dvojic „hora - katedrála“, „příroda kultura“, „božské - lidské“, „sakrální - světské“. Karel Čapek ,jak prírodni, tak kulturni prostor konstruuje s použitím velkých symboli náboženských a kulturnich. Přijimá je s jejich celým, po staletí narưstajicim významovým inventárem" (s. 35). Cenné je srovnání podob humoru, satiry, groteskna, ironie a tragikomiky v dílech Karla Čapka (Válka s mloky), Witolda Gombrowicze (Ferdydurke) a Frigyese Karinthyho (Putování kolem mé lebky). Předností monografie je komparativní zřetel středoevropský, resp. česko-polsko-mad’arský, popř. česko-slovenský (srov. kapitolu nazvanou Čapkovy reflexe o ,nejbližšich vzdálených ‘ o Slovácich a Slovensku), přičemž všechny tyto jazyky autorka ovládá. Ocenit je třeba i zevrubnou znalost literatury předmětu a související teoretické problematiky psychologické, filozofické, teorie kultury aj. Jakkoli je problematika recenzované publikace bohemistická, je zřejmý její přesah do badatelské oblasti slavistické i areálové, především však antropologické, strukturně kulturologické, nebo - snad už poněkud módně - genderové.

Autorkou druhé monografie je chorvatská badatelka Mirna Šolić, absolventka bohemistických studií na univerzitách v Záhřebu a Torontu, která v současnosti vyučuje českou literaturu a komparativní literaturu na School of Modern Languages and Cultures na Univerzitě v Glasgow; spolupracuje rovněž s Filozofickou fakultou Univerzity Palackého v Olomouci. Tato univerzita vydala v českém přetlumočení (z angličtiny přeložily Monika Pittnerová a Blanka Hemelíková) i její monografii Slovo a obraz: Karel Čapek a žánr cestopisu.

Mirna Šolić ve své práci reaguje i na podněty A. Janiec-Nyitrai, resp. na její monografii Svět mezi řádky: Kapitoly o cestopisech Karla Čapka (2011). Spatřuje v ní jako dominující „archetypálni kritiku“ (s. 16), kdežto sama usiluje o zkoumání jiné, narativní, intermediální a intertextové (s. 16-17). Jsou to hlediska, která se spíše doplňují, než vylučují. V první kapitole (Hledáni společnika) se M. Šolić zaměřuje na „analýzu narativnich změn“ s cílem „ukazovat experimenty se strukturou cestopisu“ (s. 21), mj. prolnutí prózy a poezie a skazovost vyprávění. Podle badatelky Čapek „vytvárél své cestopisy okolo dialogického vztahu mezi rüznými typy adresátü a začal se „misto na popis mist soustřed'ovat na konverzaci o nich [...] hrát si a zpochybňovat konvence žánru“ (s. 157). V druhé kapitole (Cesta mezi prírodou a uměním) zkoumá „spojitost mezi vizuálnimi druhy uměni a literaturou“ (s. 25), jejíž kořeny spatr̆uje v teoretickém programu i praxi poetismu. Analyzuje tzv. ikontext, ekfrázi i vizuální elementy samotného Čapkova jazyka. Třetí kapitola je 
pak nazvána Čapkova próza a drama jako zvláštni druh cestopisného psani a zabývá se v ní „prvky transponovanými z Čapkových cestopisů [...] do jeho beletrie“ (s. 31). Nabízí tak „dalši možnost, jak číst Čapkovo dilo z pozice, $v$ niž je cestováni dominant-

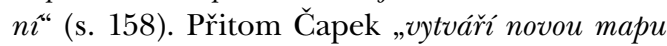
Evropy z pohledu čského cestovatele, který s sebou nese svou lokálni autentickou českou identitu“, aby současně „redefinoval ideu českosti“ (s. 158-159).

Už v úvodu monografie autorka konstatuje „experiment se skazovým vyprávěnim“ (s. 26), související přímo s Čapkovým hledáním „obyčejnosti“, resp. „obyčejného člověka“: umělec propojuje „rioznými zpiosoby vizuálni a verbálni proky, čimž vytvárí intermediálni narativy“ (s. 27), kdy „využivá vizuálni vlastnosti samotného jazyka, a to jeho gramatických kategorii, prednesu a barev, aby simuloval maliřrsé kvality proživané cizi kultury“ (s. 28), dále umělec „aplikuje ekfrázi“ chápanou jako „explicitni literárni ztvárněni vizuálního uméleckého dila“ (s. 28, její přítomnost M. Šolić spatřuje především v Čapkových Italských listech), a „konečně uplatñuje vlastni karikatury a ilustrace (které pưvodně představuje jako černobilé kresby, až později se objevuji barevně), jež vytvořil během suých cest a vypiloval po návratu domü“ (s. 28-29). Takto utvářený „ikontext“, tedy „kombinaci obrazů a textu“, autorka pečlivě analyzuje.

Mirna Šolić navazuje na bohatou „čapkologickou“ produkci domácí i zahraniční, především pak anglickojazyčnou. Jakkoli je badatelčina argumentace stylově a pojmově „odbornější“ než esejistický styl A. Janiec-Nyitrai, je nutné i na adresu této monografie dodat, že dobové kritické soudy (resp. odsudky) některých stránek díla K. Čapka nejsou projevem zlé vůle ani apriorního ne-porozumění a ne-schopnosti porozumět.
Kritik, včetně toho ideologického, do svého hodnocení, podobně jako vypravěči v Povětroni, vkládá svá očekávání, programy a poetiky, své preference umělecké, ideové, někdy i politické (včetně hodnocení cestopisných próz), o čemž svědčí soudy nejen monografií citovaného Bedřicha Václavka. Škoda rovněž, že autorka nezasadila Čapkovy cestopisy do vývojové řady vedoucí od husitských a humanistických cestopisů (cestopisných deníků) přes literární žurnalistiku 19. století (např. Nerudovy „studie“ a „obrazy“) až do první poloviny 20. století, v nichž by minimálně využití „,vizuálních vlastností samotného jazyka“ jistě nezůstalo bez odezvy. Svědčí o tom i některé autorčiny poznámky (např. na s. 32 o motivu poutníka - alegorického cestovatele v Komenského Labyrintu světa a ráji srdce). Jen na závěr, v kapitole nazvané Epilog, čteme, že „téma cestováni“ se vždy „pojilo s otázkou národnich a kulturnich identit" (s. 158) v dílech např. Miloty Zdirada Poláka, Jana Nerudy či Josefa Svatopluka Machara, přičemž Čapek podobně ,jako ostatni spisovatelé tohoto obdobi" už „nemusel cestopisnou literaturu využívat, aby prozkoumal postaveni své vlastni národni literatury v evropském kontextu, ale pouze proto, aby jej zar̆adil jako rovnocenně duležite“" ( s. 158-159), tedy že využíval cestopisy „spǐse $k$ estetickému zpochybněni hranic a funkci tohoto populárniho žánru“ (s. 159).

I přes naznačené výhrady je nutné konstatovat, že obě monografie vytyčený cíl, daný v prvním případě „sondami“ a v druhém analýzou „slova a obrazu“, naplnily a představují cenný příspěvek do současného „čapkologického“ bádání.

E-mail: alexej.mikulasek@seznam.cz 